Fecha de recepción: diciembre 2010

Fecha de aceptación: julio 2011

Versión final: marzo 2012

\section{El autor: instrucciones de uso}

Viviana Suarez *

\begin{abstract}
Resumen: En el nuevo horizonte de producción de obra, la figura del autor aparece como una amalgama de imágenes que se han ido depositando a través de un laberinto de manifiestos, políticas y actuaciones devenido historia del arte y el diseño, sobre todo en los últimos 100 años. Lejos de aclararse el panorama de las últimas dos décadas se ha enturbiado con el desarrollo y la adopción de los nuevos medios tecnológicos, que problematizan aún más un panorama de por sí complicado. El autor nunca ha sido una figura fácil de llevar con uno, desde su aparición en los albores de la historia de la modernidad y dentro del territorio geográfico, cultural y filosófico europeo. En territorios periféricos como los nuestros, la problemática se enriquece con la polarización entre dos conceptos agonísticos: identidad y ajenidad, que jamás durmieron pacíficamente en un mismo lecho.
\end{abstract}

Palabras clave: anonimia - autor - intertextualidad - objetividad - parodia - realismo - subjetivización.

[Resúmenes en inglés y portugués en la página 178]

${ }^{(*)}$ Arquitecta (UBA) y Docente. Profesora de la Universidad de Palermo en el Departamento Audiovisual de la Facultad de Diseño y Comunicación.

En estos tiempos, la figura autoral se nos aparece como un lugar sino trágico al menos incómodo de ocupar. La tópica del autor ronda la de un enunciador afectado por el estado tecnológico en el momento de la producción y por la relación con aquellos enunciatarios a quienes se dirige, esto es su público. En el cruce de lenguajes que resulta de la evolución y práctica de los nuevos modos de producción (léase las tecnologías digitales), la figura del autor es quizás la de una interpelación de puro deseo tendido hacia los otros: de comunicación, de visibilidad, de identificación, de reconocimiento, de circulación, de publicidad. Dado este panorama, podríamos interrogarnos -usando una metodología cuasi arqueológica- acerca de cuáles fueron las situaciones que produjeron un emborronamiento tal de la identidad autoral hasta convertirla en una cuestión problemática. Y podríamos plantear este tema identitario desde dos aspectos: aquel que conduce a una toma de posición frente al estado de las cosas y que se refleja en el discurso del autor sobre el mundo; y su relación, en la acción productiva, con la materialidad de la obra. Marcel Duchamp fue, quizás, uno de los primeros artistas en señalar que la obra de arte se 
había ido convirtiendo en un trozo de lenguaje opaco. Y este develamiento produce todavía hoy un entorpecimiento en las relaciones límpidas entre el autor y su público. Aunque el deseo de comunicación de sentido aún persiste, se ha perdido la transparencia del medio o la obra como medium. Desde su famosa exhibición del orinal titulado Fuente firmado como R. Mutt, cualquier persona cercana al campo del arte está compelida a declarar su inocencia -o no- en términos estéticos en forma de transparencia del contenido objetual. Y esta contaminación no está sólo cifrada en el gesto expresivo de la subjetividad enunciante, sino que alcanza el polo de la objetividad; sospecha escenificada por los constantes debates en torno a un campo altamente sensible a la denuncia de ficcionalización o inexistencia de una única verdad objetiva como es el fotográfico. Que lo enunciativo y el volverse hacia la interioridad del lenguaje es un síntoma del estado de las cosas y no una simple cuestión de tecnologías, lo demuestra el viraje de la crítica de obra. Caído el paradigma de la modernidad, y luego del repliegue deconstructivista, el polo objetivo se retrajo y se puso en cuestión. Entiéndase bien: no es que lo que llamamos realidad haya dejado súbitamente de existir; lo que se cuestiona es su coherencia interna, su mostración como totalidad orgánica que no es lo mismo que su circulación generalizada.

Hoy, cualquier sospechoso de deseo de obra pareciera encontrarse atrapado en un requerimiento de toma de posición respecto de su visión del mundo, del material heredado y de sí mismo como autor. Esto ha significado el paso del sujeto a la subjetividad y de allí un salto a la subjetivización del mundo. Una ficcionalización persistente, sospechada e inestable, parcial y constantemente mutable. Paradójicamente en la imposición de lo global, lo parcial pareciera haber reemplazado como concepto al fragmento moderno. Quizás el fragmento, como lo señalara Walter Benjamin en sus reflexiones sobre los modos de producción de la modernidad, con sus connotaciones de ruptura, selección y aislamiento estuviese aún del lado del objeto, mientras que lo parcial parece asociarse a una mirada excluyente, focalizante, desviante que se mueve en zonas amenazadas por un magma de sentido; toda nuestra cultura actual se nos presenta como un magma de sentido de difícil navegabilidad.

En este panorama nos parece interesante preguntarse acerca de quién y de qué manera produce todavía obras como autor. Es cierto que el concepto de autoría abarca actualmente un territorio mucho mayor, incluyendo por ejemplo el campo del diseño (como bien lo denota la categoría de "diseño de autor"), y se profundiza en la transmutación que producen las nuevas tecnologías que van más allá de lo reproductivo hacia lo francamente apropiativo y co-creativo, fuente de grandes turbulencias que se debaten sobre todo en lo jurídico: firma, derecho de autor, propiedad intelectual, co-autoría, entre otros. Porque el autor no es un simple sujeto de enunciación sino una voz privilegiada que pondera el enunciado lastrándolo con un número de supuestos: de autoridad aseverativa, de decir/hacer verdad, de originalidad; avalado por una red institucional que asegura, a su vez, la circulación pública de tales enunciados.

De ahí que, aunque seres vivientes, estemos atrapados en las redes conceptuales del autor tal y como se ha ido cristalizando a lo largo de la historia. Las imágenes del autor, que actúan de manera introyectada, poco conciente y cuasi-automatizada, como un suelo, al momento de producción se desgranan en un largo y complejo proceso, siguiendo líneas de cambio y permanencia heterogéneas, dando por sentado ciertos modos de pensamiento, valoración y actuación como universales pero que, sin embargo, están firmemente situados y fechados. Planteemos esta cuestión en dos momentos o actos: desde el centro de irradiación, el derrotero arqueoló- 
gico desde su aparición, consolidación y muerte en la cultura occidental (fundamentalmente europea) y desde la periferia, el retorcimiento que provoca la distancia al centro visto desde la producción sudamericana de tres autores matrices.

\section{Del lado de allá: muerte (y resurrección) del autor ${ }^{1}$}

Es evidente que al plantearnos hablar sobre la cuestión del autor pendemos de una grilla conceptual e ideológica situada geográfica y temporalmente con mucha precisión. Cualquier definición debe hacer referencia necesaria al horizonte cultural europeo, porque es dentro de éste donde la aparición primero y la reflexión crítica -y auto-conciente- sobre el tema de cierto tipo de subjetividad nominativa ligada a la producción de discursos, objetos y acciones particulares tomará algunos rasgos particulares que luego se irán universalizando. Cuánto de esta universalización es válida en cualquier contexto es un problema que nos ocupará en el segundo acto de este ensayo. Por el momento nos interesa trazar, dentro de este panorama, un itinerario por el concepto de autor desde su germen originario en la Edad Media europea hasta la declaración de su muerte a comienzos de 1980, rastreando ciertas permanencias que se presentan como ideologemas: ${ }^{2}$ por ejemplo el nombre de autor como indicador de veracidad y con ello lo que podríamos llamar el concepto de nominalidad autoral. Circa 1200, los discursos científicos se ordenan alrededor de un foco -el autor- que actúa como centro validador de orden y coherencia interna, al mismo tiempo que comienzan a circular más libremente justamente por el efecto de este reaseguro nominal de quien profiere-articula-enuncia como emisor-creador. Podría rastrearse aquí el germen de la idea de originalidad autoral, aunque todavía de manera desdibujada y difusa. Este centro gravita, además, en la idea de auctoritas, del concepto de autor ligado a un lugar de autoridad de enunciación, función que irá desapareciendo del discurso científico a lo largo del siglo XVII (Foucault , 2008, pp. 30-32), ${ }^{3}$ pero permanecerá en otras esferas discursivas como, por ejemplo, la artística. En ella nos centraremos porque es aquí justamente, dada la esencia particular de la obra de arte y el rol de ese autor especial que es el artista en el campo social, donde aparecerán las mayores tensiones que irán delineando una figura autoral muy compleja, formada por varios estratos, a veces concurrentes a veces contradictorios, cuyo imaginario actúa aún hoy en nosotros en el momento de producir una obra.

\section{Devenir epocal crítico: del objetivismo al autor en el discurso}

Desde estas coordenadas ubiquemos, como punto de origen, al autor pre-moderno tal como se delinea a partir del movimiento romántico europeo en 1800. La permanencia de esta función de la nominalización como foco de coherencia discursiva va a acentuarse con un rasgo característico del romanticismo: la aparición de una subjetividad enunciante patémica ${ }^{4}$ dentro de las operaciones estilísticas. El sujeto creador se muestra esencialmente afectado por su relación con los otros y las cosas mundanas y considera a la obra como vehículo de expresión. Aunque potenciado, este momento expresivo queda sin embargo sujeto a la norma objetivista que lo acota y limita a las convenciones de la representación mimética. Este movimiento subjetivo 
actúa más bien como una coloratura, como un entorno que tiñe una construcción perfectamente normativizada por los cánones de la buena composición y la perfección en el manejo de la técnica. Tal vez lo que se acentúe sea cierto grado de libertad con la aparición de la noción de originalidad. Esta se concentra sobre todo en los tratamientos temático-morfológicos que se irán unificando en el concepto de estilo, asociado a recurrencias y continuidades que constituyen patrones para el reconocimiento de las obras de un mismo autor ${ }^{5}$. Es interesante notar que, aunque el autor es reconocible en la obra misma por la constancia en la adopción regular de ciertos tratamientos formales o temáticos, permanece exterior a ellas, proyectándose por sobre cada una como un hilo conductor que permite situarlas respecto de una producción centrada, una vez más, en un nombre: aunque vehículo de sus emociones su creador mantiene una distancia que le impide perderse completamente en su obras. Es que el sistema representacional actúa como una red que pauta fuertemente los modos de creación, sostiene y rescata todo aquello que de subjetivización poseen estas obras, de manera que se nos aparecen como objetos únicos, de una totalidad orgánica perfecta, acabada, a la que se puede dar un sentido unívoco, garantizado por la ejecución del programa artístico propio de cada artista. Roland Barthes hablará de un autor mediador (Barthes, 2005, pp. 207-208) ${ }^{6}$, de alguien que dispone los materiales artísticos para construir un sentido que le es ya dado por su época y por la propia adquisición del manejo de la técnica.

Quizás lo que ha permanecido como el rasgo constitutivo más destacado de esta figura del autor romántico sea el de genio creador, del individuo especial y naturalmente dotado, que se manifiesta en cierta aspereza o carácter abrupto que irrumpe, como saltos disruptivos, en la continuidad coherente de la obra.

Con la aparición del realismo en la segunda mitad del siglo XIX, se producirá un movimiento de reflujo hacia el polo objetivo. Es que, dentro de esta corriente, el autor tomará una posición más militante tanto frente a lo externo como a lo interno de su producción; de alguna manera podríamos definirlo como un sujeto más social frente a la fuerte carga individual que se evidencia en el romanticismo, y su correlato será su auto-percepción como testigo epocal y a la obra como documento. Es notable como el realismo hará descansar este sentido de testimonio especialmente en una concepción centralizada en la ocularidad, aun en el caso de la literatura. En esta época el autor vuelve a ser un veredictor, un productor del decir-hacer verdad, al mismo tiempo que garantizará la objetividad de su objeto por una cuidadosa interdicción en la exhibición del trabajo de construcción. De esta manera, asegura un sentido universal compartido, ya que el enunciado se presenta de algún modo desde una posición ubicua aunque determinada. La posición del autor realista sería la del testigo privilegiado, no tanto por haber estado en un lugar y momento oportunos, sino por su capacidad de transponer en formas artísticas todo lo que ha registrado. De esta modo, las dotes más preciadas, descontado el manejo de la técnica, serán: el poder de percepción de mínimos detalles y la capacidad de retención, ambos ejes que sostienen el paradigma reproductivo del realismo. Este rasgo del autor testigo llevará a la adopción de un compromiso manifestado como toma de posición ante lo enunciado ${ }^{7}$, lo que Barthes caracterizará como la esencia del autor realista: el escribir para otros (Barthes, 2005, p. 208). ${ }^{8}$ De ahí que la creación sea considerada más como un deber social que como un placer, y el hecho de producir se manifieste como una carga o padecimiento inevitable aunque lo manifieste sólo privadamente. Quizás por la inevitable conciencia de que su lugar en el tejido social se vuelve cada día más precario y la necesidad de existencia de su obra menos evidente. 
Es sorprendente comprobar cuánto retenemos todavía hoy de estas figuras autorales, trascendentes a sus obras, poseedores de una biografía un tanto épica en la que puede leerse el proyecto -total ${ }^{9}$ o parcial- que sustenta y da sentido a toda su producción: la vida como pauta de interpretación (Compagnon, 2002, p. 54). ${ }^{10}$ Quizás la ilusión del autor como voluntad creadora, de una conciencia plena que da forma -dice- muestra el mundo, se apoye todavía en el basamento de esta imagen de autor realista, manteniéndose como utopía reconciliadora o lugar al que se añora regresar.

\section{Crisis del objeto: la sospecha de construcción de obra}

Este lugar sólo existe hoy como una virtualidad deseable, como aquella fuerza protensiva que motoriza el deseo de autor. Porque esta figura tan seductora, un tanto heroica, fue refutada por la modernidad.

Quizás podríamos describir -como paradigmáticas- dos figuras autorales que fueron modernos a pesar de sus deseos e intenciones, e ilustran el comienzo de esta crisis a fines del siglo XIX: Charles Baudelaire en el campo literario y Edouard Manet en pintura.

Baudelaire, autor del exilio interior, tanto por asumir su extrañeidad respecto al mundo como por su modernismo formal, ilustra perfectamente el sentido literal de la ex-centricidad. Figura desgarrada entre una postura cercana al romanticismo, de una subjetividad afectada y resistente frente a un mundo moderno que cambia inexorable e implacablemente alienando la vida vivida, y la profunda transformación de la forma literaria: temas en el límite de la poesía, imágenes extrañas que apelan a experiencias sinestésicas, remisión a estados oníricos u alterados por la droga, poemas en prosa. Tal modernidad provocó su exclusión de la lista de artistas consagrados con que la institución literaria de la época sancionaba la jerarquía autoral (Proust, 2006, p. 137)..$^{11}$ El mismo desgarro percibimos en Edouard Manet: las mismas aspiraciones a figurar entre los autores clásicos, la búsqueda de reconocimiento por parte de la institución artística representado por el Salón Nacional, la misma ruptura radical de las formas plásticas. ${ }^{12}$ Es importante detenerse en ellos porque sus casos ejemplifican una situación de pasaje o puente entre dos concepciones que empiezan a polarizarse: lo clásico y lo moderno. Ambos artistas ilustran -en la hermenéutica del autor- el abandono de cierta concepción biográfica vitalista y su reemplazo por la construcción de una cierta tipología autoral. Se trata de constituir un Ideal de autor que funcione como lugar simbólico más que real y, por lo tanto, un adelgazamiento de la carne y un aumento equivalente en el imaginario. Sus vidas se presentan como una reconstrucción retrospectiva y selectiva de aquellos momentos que pueden constituir el sentido como accionar programático respecto de su posición y actuación en relación al arte: son vidas-relato, quizás podríamos decir un tanto exageradamente, hagiografías de autor.

La reciente aparición de la fotografía contribuyó a suplementarle una fijación icónica que sirvió para acentuar la ilusión del par realidad-verdad: la esencialidad de huella indicial de la fotografía, eso que Walter Benjamin definió como su propiedad aurática, ancló en un referente real la construcción del personaje imaginado. Frente al retrato de Baudelaire realizado por Nadar proyectamos, casi automáticamente, esta figura de artista asocial, trágico, anonadado, un poco extraño en su propia época y condición social; retrato que en el mismo acto de representar coagula, resume, cristaliza un modelo icónico, una armazón que incrusta con gran fuerza sobre 
la imagen de ese sujeto empírico un sujeto ideal a quien imitar. La fotografía contribuyó de este modo a perfeccionar el mito autoral-nominal al otorgarle -más que una cierta apariencia- 13 un cuerpo en el cual encarnar el nombre. Desde entonces se instaló una situación paradojal: la fotografía provee un anclaje concreto en lo existente -este hombre- y el nombre individualiza un modelo matriz identificado con operaciones y procedimientos genéricos y de estilo -lo baudelariano-. El autor comienza a introyectarse en sus propias obras, a volverse inmanente respecto de ellas, precisamente al revelarse éstas cada vez más como objetos construidos y perder su carácter de entidad orgánica autónoma. Justamente esa será una de las operaciones más criticadas e incomprendidas por los contemporáneos de Manet: es el caso, por ejemplo, del célebre Almuerzo Campestre con su sátira a la representación clásica tanto en el tratamiento del tema como en la heterogeneidad del plano plástico donde utiliza su famoso recurso de lo inacabado o apenas esbozado.

\section{Crisis del objeto: la fragmentación de la obra}

El paso siguiente a la refutación de la figura autoral clásica implicará una toma de posición y operaciones explícitas sobre el estatuto del autor respecto del arte tanto como de su metodología de trabajo.

En Contra Sainte-Beuve la hipótesis central que intenta demostrar Proust gira en torno a su posición crítica respecto de la hermenéutica clásica tal como era entendida por el crítico literario Sainte-Beuve. El modelo basaba la interpretación de las obras en una cuestión filológica: reconstruyendo la vida íntima y social del autor en el momento de la producción era posible llegar a conocer el sentido completo y final de la obra. La postura polémica de Proust dará el motivo y será el motor de producción de En búsqueda del tiempo perdido, porque delineará, entretejida e inseparablemente del trabajo de escritura, como una de las tantas líneas desarrolladas en esa obra, otra figura autoral. Esta figura se irá armando con la descripción y narración de varios personajes vinculados a distintas disciplinas artísticas, a través de los cuales Proust reflexiona sobre los tipos de relación entre creación y experiencia vital, o sobre recepción y perdurabilidad de la obra y del propio artista. Esos personajes son el músico Vinteuil, el escritor Bergotte, la actriz Berma y, por supuesto, la voz narrante que se presenta como el autor de la obra que se escribe ante nosotros. Esta puesta en escritura in acto iniciará de alguna manera una cuestión absolutamente moderna: la exhibición del objeto artístico como un algo ficcional o artificial. Y esto, que pareciera no ser contradictorio con el concepto clásico de obra que obviamente es un objeto puramente ficcional, fue explícitamente ocultado por la producción anterior, velando todo rastro de construcción, de trabajo para crear la ilusión de absoluta organicidad del objeto ${ }^{14}$ que se ofrecía a la fruición estética. Por lo tanto es interesante señalar que la develación constante de la urdimbre textual, ese relato incesante de la realización de escritura, el mostrarse recurrente y obsesivamente como escribiente -toda la Búsqueda puede leerse como el relato épico de una escritura (Barthes, 2005, p. 158)- provoca en el lector una fuerte sensación de un haciéndose, armándose, cosiéndose de algo que, objetivamente, está completo y definitivamente acabado. Por otra parte esta misma forma de abordar la acción del escribir convierte al texto en una colección de fragmentos, unidos por la referencialidad a un exterior vivido que suscita una serie de reflexiones acerca de las nociones de experiencia y recuerdo, 
que posteriormente se hicieron tan famosas como la vulgata o síntesis justamente del sentido general de la Búsqueda ${ }^{15}$. Sin embargo, para Proust la única referencialidad externa válida está hecha de una interioridad: lo que vale la pena comunicar en una obra de arte no es tal o cual experiencia sino la manera particular e irrepetible con la cual cada uno de nosotros aprehende intelectiva, emotiva y sensorialmente los hechos que le suceden. La esfera que describe el texto siempre se mantiene muy próxima al radio de percepción y acción de esa subjetividad delegada en la voz narradora, siempre en primera persona y casi nunca llamada por su nombre. De esta manera, las constantes apelaciones implícitas al acto de la lectura -y a sí mismo como alguien que lee ${ }^{16}$ más que alguien que escribe- inaugura esta noción moderna de un cambio en el foco del sentido: ya no más el autor como norma de interpretación sino el lector como lugar privilegiado para completar el sentido que ya no es ni universal ni dado de una vez para siempre. Sentido que debe ser conquistado y que puede ser decepcionante en su primera recepción, como relata el propio narrador sobre su experiencia de la representación de la Berma del personaje de Fedra de Racine. El sentido se abre ahora como un enigma que no puede abarcarse con la biografía del autor, porque no es en el flujo experiencial vivido donde hay que buscar un proyecto que ni siquiera el propio realizador controla en toda su complejidad, sometido él a la búsqueda de sí mismo en una identidad cambiante que sólo adquiere inmovilidad y completitud en la muerte. Y, sin embargo, si lo que se abre en el fondo de esta cuestión es la pregunta por la vida de las obras y -unido como un apéndice- la perduración del autor a través de ellas; la obra en sí misma se revelará como un objeto frágil y mortal, cuya supervivencia no es infinita sino sólo mientras haya alguien que pueda entender "su lengua", y que luego, al perder sus lectores y con ellos su sentido de existencia, quedará convertida en mera coseidad muda. Este trágico vértigo del tiempo como devorador-destructor, que pone al autor al borde de un precipicio y que lo obliga a justificar la necesidad de su trabajo y su producción, inaugura la relación moderna autor-obra y marca la salida del sistema del realismo a la vez que bloquea su posibilidad de regreso. A partir de este momento podemos comenzar a considerar una nueva concepción de la figura autoral, en la cual se abandona la idea de premeditación o proyecto de obra, lo que implicaba la tarea crítica de reconstrucción del contexto original de producción para fijar el sentido justo por otra en la cual la intención no preexiste ni se encuentra en otro lugar que no sea dentro de la propia obra, en el acto de su construcción (Compagnon, 1993, pp. 49-54). Con una obsesividad cercana, Marcel Duchamp reflexiona en sus obras sobre el lugar del autor en la modernidad. Me parece que puede considerarse su acción realizativa desde esta concepción de inestabilidad y búsqueda una vez caído el nexo claro que unía el nombre de un autor a determinadas formas de producción que podían ser leídas en su estilo y contenido particulares. Duchamp asume como dato objetivo que la perdurabilidad de la obra, su subsistencia como objeto valorado que trasciende a su creador y su época, ya no es incuestionable o, más bien, intocable. Las obras duchampianas se presentan frágiles desde su misma materialidad (papel, cartón, cuero y -sobre todo- vidrio) y enigmáticas, propiciadoras de sentidos multiestables. Es evidente la apelación a una lectura que es "reescritura", a la interpretación activa de sentido -uno, muchos, cualquiera- que Duchamp deliberadamente suspende. Esta apertura se señala explícitamente en dos operaciones típicamente duchampianas: el inacabado -con la intervención del azar en la construcción de la obra- y el uso de distintos medios en una misma obra 17. Todas estas operaciones, que generarían un cimbronazo profundo, modificando radicalmente la concepción y forma de trabajo con materiales y técnicas artísticas en la modernidad 
tardía, colocan al autor fuera del alcance de cualquier operación hermenéutica final, al abandonar completamente el concepto de planificación premeditada. El propio Duchamp definirá el coeficiente de arte de una obra como la relación entre la planificación conciente del autor y el grado de intervención del inconciente, la irrupción de fuerzas que no pueden controlarse: cuanto mayor sea esto último, mayor cuota de arte. Por ejemplo, el método con el que realiza la obra Tres metros patrón proviene del campo científico: planteo de una hipótesis, realización de la prueba experimental y registro de los resultados, que en este caso es la propia obra, exhibida. De la misma forma se podría comparar qué sucede con la fijación del icono autoral en el retrato fotográfico. La imagen más famosa que circula de Marcel Proust lo muestra con aire indolente, la cabeza recostada sobre una mano y los ojos entornados, lo que ayuda a consolidar el mito de artista excéntrico, que vivía y trabajaba sólo por las noches, padeciendo sus crisis asmáticas 18 que lo colocaban en una situación vital de extrema fragilidad; la imagen de languidez y nocturnidad que encaja perfectamente con la del mito decimonónico de autor marginado y del don artístico como una carga difícil de sobrellevar. Distinto es el caso de Marcel Duchamp quien, englobando en sus cuestionamientos a la modificación del estatuto social del autor el campo de la imagen, introducirá un rasgo lúdico o paródico a esta fijación mítica de la figura autoral. A sus retratos del Marcel Duchamp masculino, sereno y racional, se le adicionan otros en los que se presenta como su heterónomo femenino Rrose Sélavy, fotografiado por Man Ray. De esta manera, el trabajo obsesivo de Duchamp recae sobre la nueva relación entre el autor y los campos culturales y económicos de la modernidad, leídos en términos de una ausencia total de necesidad de obras y su correlato de autogestión financiera, al mismo tiempo que señala la migración de la supuesta capacidad del autor en el manejo de los campos técnico y representacional de su disciplina al de la necesidad de plantear problemas siempre nuevos referidos al concepto general del arte. La imagen del autor comienza así a movilizarse como adaptación al juego de la oferta y la demanda propio de las sociedades de mercado. Y con ello se desdibuja la identidad fuertemente anclada hasta ese momento, en el nombre y el retrato. Del artista como personalidad original al artista como gestor de su propia imagen diferenciante.

A partir de estos señalamientos y trabajos surgirían un nuevo tipo de obras -los happenings, performances y actings-, que cuestionaron la posibilidad misma de obra como duración. Dentro de este contexto es quizás cuando cobra sentido hablar de la muerte del autor, no como ser empírico claro está, sino como aquella figura identitaria que garantiza la enunciación de contenidos pausibles de ser interpretados. La fragilidad del concepto autoral y, al mismo tiempo, la imposibilidad de volver a una total anonimia, es vivido como algo abismático y, por esta razón, violentamente operativo.

\section{Crisis del sujeto: la muerte del autor}

Dada la pérdida de la inocencia creadora, una obsesión por el paso del tiempo, los procesos durativos, incoativos y terminativos comenzarán a marcar las líneas predominantes de acción en la realización artística. Podríamos sintetizar estas experiencias como siguiendo dos caminos: el que busca recuperar la obra como objeto -aunque sea como residuo de un gesto- sobre el cual impresionar un sentido; y el que asume el carácter efímero en el interior de la producción. Bajo la primera concepción subyace la creencia en el efecto durativo como productor de res- 
puestas significantes. Una vez desplazado el centro hermenéutico del autor-creador al lectorauditor-observador como agente activo, la obra actúa como base de un efecto de acumulación de sentidos proyectados por la sucesión de lecturas, desacoplados totalmente de la intención original. Afecta esto a la valoración de la obra como objeto de arte, consideración que ahora debe validarse o confrontarse continuamente con cánones y re-conceptualizaciones siempre cambiantes. Cada obra encuentra su sentido en una situación dada, y es así como objetos que el propio autor pudo haber considerado menores o directamente no-artísticos-como bocetos, primeras versiones o cartas- pueden devenir obras con valor estético autónomo superando el de documento. El autor concientemente provee entonces objetos difusos de sentido borrosos, cuyo antecedente habíamos señalado en las obras de Duchamp. La obra como resto del gesto autoral -que es en sí mismo el acto artístico- puede rastrearse en las escrituras automáticas de los poetas surrealistas, en sus obras colectivas como los cadáveres exquisitos, en el action painting de los artistas americanos de la década de 1950, cuya figura paradigmática se concentra en Jackson Pollock, en las pinturas realizadas con cuerpos femeninos revolcándose sobre la tela de Ives Klein; para citar algunos pocos de múltiples ejemplos. La relación entre el producto final y el acto que lo produce podría encuadrarse en lo que en lingüística se denomina embrague: esto es, debemos reconstruir necesariamente el contexto, de producción en este caso, para acceder a la significación completa de la obra. Desligada de su proceso de creación, de su contexto originario, la obra apenas puede mostrarse como algo susceptible de ser valorado y exhibido. Este carácter exhibitivo de la obra clásica -y en gran parte de las de vanguardia- es lo que acaba por ser destruido, recayendo la justificación de la existencia de la obra en sí en el momento de la creación y el gesto del artista. Otra variante de arte performativo, en relación con la temporalidad, será la realización de proyectos artísticos que, por su escala, pueden considerarse como una nueva versión de lo monumental. Los trabajos de Robert Smithson sobre grandes zonas de territorio que por su dimensión y dificultad de acceso sólo son accesibles a través de fotografías o videos; las esculturas deconstructivas hechas en y con edificios abandonados o a punto de ser demolidos de Gordon Matta Clark; el proyecto de los 7.000 robles de Joseph Beuys o los envoltorios de edificios completos y fachadas de Christo muestran una concepción de lo monumentalizable y su connotación de perdurabilidad amenazados por la consumición, la pérdida y la destrucción.

Con esto aparece una nueva figura autoral: la del artista performador cuya imagen es una pura corporalidad. La lingüística define la performatividad como aquella capacidad del lenguaje que realiza diciendo, como en el caso de un juramento o una declaración. Precisamente, el acto -predominantemente gestual- constituyente de obra es el sentido final de la obra. La imagen que ahora circulará mayoritariamente mostrará al artista en acción, ${ }^{19}$ y será el video, con su capacidad para registrar el movimiento, el que irá reemplazando a la fotografía como representación icónica del autor. Esto dará una especie de humanización del autor al multiplicar su figura en un flujo de imágenes de fuerte connotación narrativa -el relato de una hacerse-, contrapuesto al congelamiento en ese icono condensador que era la imagen fotográfica. La humanización contribuirá a la proyección sobre el nombre de una presencia más centrada en lo corporal, al ser el autor un sujeto que ejecuta más que un sujeto que es mirado.

En el segundo camino hacia la asunción del carácter efímero, la obra perderá todo valor en sí misma como objeto, siendo reemplazada por un deseo o tendencia de obra. Roland Barthes (Barthes, 2005, pp. 203-205) lo definirá, a propósito de la (im)posibilidad de seguir producien- 
do un género determinado -novela- en el contexto de la muerte del autor, como una forma de creación rapsódica, es decir fragmentaria, donde lo que se rescata no es tanto una forma cerrada -la novela- sino un clima -lo novelesco-, zona de tensión hacia la que se tiende produciendo una deformación topológica del objeto, que se presenta en realidad como campo de fuerzas, ${ }^{20}$ un algo que nos interpela -como lectores, como enunciatarios- desde el deseo de escritura más que desde lo escrito. El autor se replegará totalmente en el interior de su obra, en operaciones de intertexto, en las cuales co-creará desde su historia, su relación con el pasado y lo contemporáneo, sus lecturas, una nueva amalgama que se presentará como obra cosida (Barthes, 2005, p. 205) con fragmentos de otras obras en una tarea de apropiación, traslación y transfiguración. La operación de intertexto es definida por Gerard Genette (Genette, 1989, p. 13) como aquella relación que une un texto B (el hipertexto) con otro A (el hipotexto), que no aparece explícitamente pero sin el cual el texto B no podría existir. Algunas operaciones ya practicadas tanto por Proust como por Duchamp, como la parodia, el pastiche o la cita, asumen que toda obra es, en realidad, un proceso re-creativo, en el cual cierto autor o autores actúan como matriz de producción contribuyendo a la procreación de una obra vástago obtenida por filiación difractada (Barthes, 2005, pp. 190-198). En este contexto Barthes definirá el placer del texto (léase de cualquier producto artístico considerado como objeto de lectura) como una vuelta al autor, quien ya no se encuentra en otro lugar que no sea el interior de la obra. Así - dirá- su vida queda reducida a biografemas, rasgos que arrojan una luz iluminadora que nos conduce, como lectores, como destinatarios, nuevamente a la producción, en un circuito incesante en el cual cada lector se convierte, por amor al autor leído, observado, en creador de un nueva obra. Por eso ahora, lo que se enmascara detrás del nombre no podrá cerrarse en una identidad fuerte, completa y distante, sino que serán apenas unos pocos detalles, manías, gustos que puedan trasmigrar a otro cuerpo futuro, (Barthes, 1997, p. 15) en una ponderación del acto de lectura como el nuevo centro - enigmático- donde se concentra la intencionalidad de obra. El autor ya no es una persona sino un cuerpo disperso en su obra como "las cenizas que se arrojan tras la muerte" (Barthes, 1997, p. 15). En el terreno de lo plástico podríamos evocar a Victor Grippo, autor cuyo cuerpo formado por esquirlas de vivencias trasmigra en sus obras por una operación alquímica, inmovilizando objetos orgánicos en formas poéticas.

\section{Del lado de acá: el autor en las comarcas del chiste 21}

Aquellos que trasegamos estas comarcas periféricas y australes sabemos que ficcionalizar el mundo, suspender la creencia en una realidad sin fisuras, descreer del causalismo sin sobresaltos o de la regla que excluye el imprevisto, no presentan mayores dificultades. Digamos sin grandes rubores que habitamos un área periférica y que, por esta razón, los grandes temas que deben ser absolutamente definidos, comentados, debatidos nos han llegado, la más de las veces, retardados, colapsados, deformados por deflación o inflación, pero nunca impolutos.

Esto no es menor en lo que a la cuestión de la autoría se refiere. Porque ¿̇se puede ser un autor completo cuando la propia identidad cristaliza alrededor de uno mismo como el otro? En el momento de producir obra quizás involuntaria y casi inconscientemente nos miramos con los ojos del otro -que no somos nosotros mismos-y desde allí moldeamos el imaginario que nos 
asienta en cierta idea de autor-creador desde un recinto que talla lo esperable. Osvaldo Lamborghini lo pone en estas palabras:

Cuando Rimbaud dice me voy, hay que entender que se viene; lo que pasa es que con el afrancesamiento uno lee que Rimbaud se va y por identificación uno se está yendo con él. No, vos no te vas con él, estás acá esperándolo. Se va quiere decir que se viene para acá. África, las pampas argentinas, todo igual para Rimbaud (El lugar del artista, 1980, p. 48).

$\mathrm{Al}$ igual que el personaje de la novela de Rivera, La vorágine, preferiría pensar a ésta como una tierra de desmesura e incorrección; como una atmósfera que afecta, por turbación o desasosiego, a quienes le es dado habitar en ella o, al menos, emigrar trastornado pero difícilmente intocado. Esta marca geográfica -y no menos política- del territorio suramericano puede convertirse en una posible vía de construcción de una identidad que me gustaría creer heterónoma, produciendo autores de figura bifronte, desgarrados entre la producción y la espera. Y, nuevamente, ¿ cómo asumir la autoría cuando la identidad se esquiza? Tal vez la salida sea la caída en la fuerza del mito.

Podríamos evocar tres figuras como aquellos autores matrices de los que hablaba Barthes en la encrucijada entre lectura y creación. Los tres comparten ciertos rasgos: la reflexión sobre la creación, la relación con su lugar en el mundo y la posibilidad de construir identidades temáticas y formales que asuman esta particular situación paradojal de ser europeos en la comarca americana. Me gustaría pensarlos como senderos por los que transitar la diferencia dentro del unísono. Citando a Macedonio Fernández: "todo es verdad aquí, si nada lo es en el alma de quien descuida regar sus sueños, mimar sus esperanzas” (Fernández, 2001, p. 17).

\section{Macedonio Fernández: autor anónimo}

El problema del estilo es, en el fondo, un desacato a la autoridad, un desafío a las garantías que organizan el discurso, sea Dios, la institución arte o el yo. El problema de Macedonio es que sospecha que la obra inmoviliza al sujeto-autor que respira, palpita, transpira y siente en una fluidez incesante de experiencias. Dado esta situación ¿cómo prescindir de una figura congelada del autor sin prescindir del sujeto de la experiencia? El yo que habla en los textos de Macedonio es, por un lado, un yo distraído, inmerso en un estado de flotabilidad que no es fijado ni recogido por ninguna finalidad o sistema. Oscilante en el filo de la nada, escribe sin reivindicar un nombre: en la lucha del individuo y la especie, Macedonio intenta conservar el individuo sin matar la corriente vitalista de la especie y por eso será el creador de una postura filosófica frente al mundo, que definirá como una posición esencialmente idealista 22 : la del almismo ayoico. Así dirá en el Poema de trabajos de estudio de las estéticas de la siesta (en busca de la Metáfora de la Siesta): "sin la puerilidad del novelismo o biografismo, del dónde, cuándo, cómo y a quién aconteció el poema” (Fernández, 2001, p. 73).

Esta -podríamos llamar retrospectivamente- deconstrucción de la identidad nominativa heterónoma respecto de la obra se troca en entidad enunciante; al nombre como una figura fuerte 
condensada en la firma-el retrato, un yo como amalgama de deseos y afecciones posado sobre un mundo sensorial concreto: una anonimia vitalista. Esta relación con el mundo como experiencias discontinuas, entre el sueño y la vigilia, hace saltar la forma novelada. En Una novela que comienza justamente lo que se encuentra son sólo comienzos, introducciones, prólogos y prolegómenos, anuncios ${ }^{23}$ que se deshilachan o funden unos en otros; textos generosos en recodos, acotaciones, meandros, digresiones. El objeto novela no termina de cuajar, de arrancar, de formarse. El autor es una especie de semiotizador recreando el mundo con los signos que va dispersando a lo largo de un texto disperso, sin trama, pura interpelación. Es que justamente, las obras de Macedonio buscan la complicidad con un lector al que se dirigen constante y abiertamente: "Al lector: lectura de ver hacer; sentirás lo difícilmente que la voy tendiendo ante ti. Trabajo de formularla; lectura de trabajo: leerás más como un lento venir viniendo que como una llegada" (Fernández, 2001, p. 73).

Precisamente este trabajo - de formulación, de lectura- tampoco puede fijarse en una forma final y definitiva: por eso Macedonio será aquel autor que escribirá sin publicar: "casi únicamente vive dedicado al pensamiento metafísico, acerca de lo cual tiene mucho escrito y para publicar, pero nada publicado, lo que lo mantiene en gran concepto" (Fernández, 2010, p. 41), le comentará Domínguez a un Hobbes trasportado desde la Inglaterra del siglo XVIII a la Buenos Aires de 1900, en plan de presentarle a Macedonio Fernández, metafísico que tiene algunas teorías para refutarle sobre la consistencia del mundo de la vigilia.

\section{Osvaldo Lamborghini: autor del subrayado}

Si Macedonio escribe sin publicar, Lamborghini asumirá la necesidad contraria como forma de subsistencia: la de publicar sin escribir. La parodia macedoniana se dirige al corazón del escritor sacerdote, como definiría Barthes al autor de la novela realista (la novela mala según Macedonio) disolviendo al sujeto en la universalidad del escribir (Barthes, 2006, pp. 208-209). Lamborghini, en cambio, tendrá un problema de digestión en relación con su mundo de referencia, y sus textos de alguna manera corrompen a ese mundo externo en una puesta en discurso de un ritual de sacrificio de lo real por lo textual. Así sus textos se vuelven visiones teratológicas; precisamente la escritura funciona como una máquina óptica deformante por una operación paródica, a la vez que incómoda para el lector que lee obra alucinadas y se ve precipitado dentro de un torbellino de frases. Es que los textos de Osvaldo son abigarrados, barrocos, sin treguas o respiros, y su parodia -y operación principal de casi todas sus obras- es sobre la frase, aquella entidad tan preciada por la novela realista, que es sumergida, en El niño proletario, El Fiord, en un juego entre la cultura erudita y popular, entre la retórica y la imprecación más procaz. La mecánica de construcción será la del subrayado y la obra apenas tiene un referente externo que no sea puro texto: Lamborghini es un autor del intertexto. ¿Y la subjetividad que escribe? “de la razón, haberla y perdido... del terrorífico 'el mismo yo' (o Yo), y no del escribible (novelable, especialmente) 'yo mismo'. Al que aventuras no le faltan (nunca) para contar, pues no carece, más bien (nunca), de argumentos” (Lamborghini en Laddaga, 2006, p. 114). El lugar del poeta para describir el mundo, para narrar sobre aquello que sucede, dirá Osvaldo, es el no lugar 24 , sólo existe por dentro de la escritura, de los textos que se ha leído que actúan como 
sobredeterminación y sobre las prohibiciones que la lengua misma dicta en el momento de escribir (El lugar del artista, 1980, pp. 48-51). El autor lamborghiniano es un escritor estrictamente realista, pero este mundo aparece cifrado en clave de formas literarias, trasmutado en $-\mathrm{y}$ trasmigrado a- un puro acto escritural. Y su relación es la de la parodia que es "como un amor fracasado". "Uno escribe en función de los textos que ha leído. Lo que uno ha leído actúa como sobredeterminación. La vida -dirá- es un texto, que es una sobredeterminación mayor" (El lugar del artista, 1980, p. 51).

\section{Glauber Rocha: el arte en trance}

El territorio que se ocupa con las operaciones de subrayado es el de la escritura desde acá, ya que "en el texto mismo la parodia es un mundo" (El lugar del artista, 1980, p. 50). Las frases ya hechas y rescatadas para habitar en otro texto, son una forma de ocupación para Lamborghini. Para el cineasta Glauber Rocha el territorio a ocupar es un lugar alienado por preconceptos socio-políticos y culturales, que necesariamente necesita ser pensado desde otras coordenadas geográficas e ideológicas. Al cine digestivo de las grandes producciones brasileñas de los ' 50 y ‘60, Rocha -y toda la corriente del Cinema Novo-, opondrá una estética del hambre y una suspensión de la realidad en el ensueño. Cercano a Macedonio pero desde otra militancia artística, Rocha denunciará a "los autores que se auto-castran en un formalismo estéril" (Rocha, 1993, p. 26) y abogará por una asunción de la incivilización del territorio americano. A la figura clara del buen -o mal- salvaje, de los exotismos, que es la mirada de los otros sobre nosotros, muchas veces automática e inconscientemente introyectada, opondrá la de la multiplicidad, de la fragmentación que producen los mitos. La esencialidad estará en el hambre, como una violencia, no primitiva ${ }^{25}$, sino una violencia amorosa, motor de estéticas propias. Rocha, al igual que Macedonio, pondrá como objetivo de su acción artística la concreción de suspender la realidad conciente, estando su mundo en trance -onírico- lo que permitirá abrir vías hacia la construcción de una identidad más profunda.

\section{Un último momento autoral}

El autor es una figura venida, recibida y totalmente apropiada. Creamos desde nuestras imágenes introyectadas de autor; producimos pensándonos autores, deseamos hacer circular nuestras obras desde nuestras subjetividades autorales. El ser autor nos coloca en una relación exacta y permanente entre el mundo que decimos o mostramos, y los destinatarios a los cuales dirigimos nuestro discurso. Las figuras autorales trabajan fantasmáticamente porque, como afirma Lamborghini, somos nuestras lecturas. También una vida autoral puede leerse, y trasmigrar hacia la nuestra, interpretándola y convirtiéndola en guía de creación. El problema que se nos presenta más insistente, más arduo, es justamente aquél que el autor dramatiza con mayor espectacularidad: la cuestión de la identidad. En este momento crítico pareciera haberse producido un regreso hacia las instituciones (desde el museo a las redes de circulación virtuales) para reinscribir en ellas algo cercano a aquella figura de la auctoritas del mundo clásico. En 
este mundo ancho y complejo, ¿ recuperar la capacidad de operatividad? ¿Escribir sin publicar, publicar sin escribir? Quizás la palabra clave en todo esto sea el deseo subyacente a toda subjetividad autoral de tomar estado público, palabra que esconde el resto de pulsión exhibitiva de toda obra y a través de ella, de todo autor: deseo de persistencia como deseo de subsistencia.

\section{Notas}

1. Desde un punto de vista más marcadamente literario, la problemática de la hermenéutica del autor fue desarrollada por Antoine Compagnon en el curso Qu'est-ce qu'un auteur? del año 2002. De este curso tomamos y trabajamos algunos conceptos básicos.

2. Definiremos ideologema como aquellas figuras del discurso que, traspasando ciertas ideologías determinadas en las que se originan, migran y se resignifican actuando como nodos de significación.

3. Estos conceptos están tomados de la Lección inaugural de Michel Foucault en el College de France en 1970 (2008, pp. 30-32).

4. El pathos se define como aquello que afecta al sujeto de enunciación y que busca un camino formal para expresar emociones. Este sujeto es casi siempre un ser afectado por su estar en el mundo. 5. En el caso de la pintura podría citarse las composiciones con marcadas diferencias de escala de Caspar Friedrich, el novedoso uso del cromatismo en la pintura al óleo introducido por Eugene Delacroix o el desarrollo del momento expresivo en la música de Beethoven.

6. "Escribir algo: ese fue el caso durante siglos; el escritor estaba en general en lugar de alguien, genérico o ficticio, de quien no era más que un simple procurador" (Barthes, 2005, pp.207-208). 7. Que puede tener una fuerte carga y compromiso políticos como en el caso de Yo acuso de Zola o una mirada más científica y distanciada como en Madamme Bovary de Flaubert, posición objetiva que no impidió que fuera llevado a juicio justamente por el realismo extremo de esta novela. 8. "Mi pluma por una causa" (Barthes, 2005, p. 208).

9. En el caso de la literatura francesa: La comedia humana de Balzac a partir de un proyecto retroactivo que unifica la totalidad de sus novelas.

10. "El autor es el nombre de una norma de interpretación del texto" (Compagnon, 2002, p. 54). 11. Escribirá Marcel Proust en el capítulo "Sainte-Beuve" y Baudelaire de su obra Contre SaniteBeuve: "El más grande poeta del siglo XIX [se refiere a Baudelaire], quien además era amigo suyo [se refiere a Sainte-Beuve], no figura en los Landis, donde tantos condes Daru, Alton, Sheé y otros cuentan con el suyo". Sainte-Beuve fue uno de los críticos que contribuyeron a forjar con sus artículos el panteón de grandes autores literarios del siglo XIX (Proust, 2006, p.137).

12. Ver el excelente estudio de A. Compagnon sobre estos dos autores en Las cinco paradojas de la modernidad (1993, pp. 13-33).

13. La diferencia con los retratos y autorretratos pictóricos reside justamente en el carácter de huella indexical del signo fotográfico que, en ese momento del 1800 y aún hoy, hace descansar la fuerza y seducción de sus imágenes en su anclaje en lo existente-real, con lo cual crea una fuerte sensación de mostrar verdad. Roland Barthes lo define como el noema fotográfico del "esto ha sido".

14. Es lo que Adorno denomina la apariencia estética de la obra de arte.

15. Nos referimos obviamente al relato de la magdalena mojada en el té de menta que sirve de 
disparador de la memoria involuntaria y las reflexiones que desencadena. 16. Lee todo tipo de signos: ver Gilles Deleuze, Proust y los signos (2002).

17. Para ambos: ver la obra La novia desnudada por sus solteros, mismo como retraso en vidrio asociada a las notas reproducidas que integran La caja verde como su complemento literario. 18. Existió una fuerte asociación -a fines de siglo XIX y comienzos del XX- entre capacidad artística y enfermedad; basta pensar en el ilustrador Audrey Beardsley, el escritor Franz Kafka, los pintores de la bohemia parisina como Amedeo Modigliani por citar algunos pocos. Este tema fue tratado de manera excelente por Franco Rella en el artículo "Enfermedades", revista Confines, (1996, septiembre) 2(3), pp. 167-183.

19. Ejemplos de esto son videos que registran al artista en el momento de producción o los realizados por los propios artistas en un trabajo de auto-documentación creativa: Picasso pintando con haces de luz, Pollock realizando una pintura sobre el piso, Aselmn Kiefer pintando con las manos sobre un lienzo enorme, para citar una mínima muestra de muchísimos ejemplos.

20. "De una fuerza que busca voluptuosa y dramáticamente su punto de aplicación”. (op. cit., p. 205).

21. Definición de nuestros territorios según Osvaldo Lamborghini en La causa justa.

22. "Las inexistencias para el idealismo son cuatro: yo, materia, tiempo y espacio, generadoras de las pseudo ideas de la Nada, por contraste con "lo sentido", el estado que es el todo del Ensueño, como lo es del ser”. (Fernández, 2010, p. 30). Uno de los capítulos de No toda es vigilia la de los ojos abiertos se llama precisamente: El mundo es un almismo, y allí, polemizando con Hobbes y Kant, Macedonio expone su concepción sobre la inexistencia de un límite entre conciencia y ensueño.

23. "El género de lo nunca habido, el de tan frecuente invocación, lo sin precedentes, será estrenado, pues él mismo nunca existió, nunca hubo lo nunca habido, en el corriente año y como es justo en Buenos Aires, la primera ciudad del mundo viniendo del campo inmediato, la única ciudad que se presta para conclusión de una vuelta al mundo empezada en ella y lo mismo para concluir las empezadas donde quiera, como lo han descubierto sucesivamente varios inexorables circunandantes terráqueos con vuelta al mundo anunciada partiendo de Berlín o Río de Janeiro, que se consumó, sin orientación indiscreta para este tramo ..." (Fernández, 2001, p. 49). 24. Dirá Osvaldo sobre el lugar desde el cual se cuenta la realidad: "si hay lugar, no hay poesía ... toda la relación con la poesía es desde ningún lugar” (El lugar del artista, 1980, p. 51).

25. "Y la mas noble manifestación del hambre es la violencia" (ibibem).

\section{Lista de Referencias Bibliográficas}

Barthes, R. (2005). La preparación de la novela. Buenos Aires: Siglo XXI.

(1997). Sade, Fourier, Loyola. Madrid: Cátedra.

Compagnon, A. (1993). Las cinco paradojas de la modernidad. Caracas: Monte Ávila.

Deleuze, G. (2002). Proust y los signos. Madrid: Editora Nacional.

El lugar del artista. Entrevista a Osvaldo Lamborghini (1980) Buenos Aires: Lecturas críticas 1

(1) 48-51.

Fernández, M. (2001). Una novela que comienza. Buenos Aires: Corregidor.

Foucault, M. (2008). El orden del discurso (4a ed.). Buenos Aires: Tusquets. 
Genette, G. (1989). Palimpsestos. La literatura en segundo grado. Madrid: Taurus.

Laddaga, R. (2008, abril). Osvaldo Lamborghini, la estrategia del paroxismo. Las ranas. Artes, ensayo y traducción. 2 (2) 113-123.

Lamborghini, O. (2005). Tadeys. Buenos Aires: Sudamericana.

Proust, M. (2006). Contre Sainte-Beuve. Buenos Aires: Tusquets.

Rella, F. (septiembre 1996). Enfermedades. En revista Confines.

Rocha, G. (1993, junio-julio). La estética del hambre. La caja. Revista de ensayo negro. (4) 26-27.

La estética del sueño. La caja. Revista de ensayo negro. (4) 27.

\section{Recursos Electrónicos}

Compagnon, A. (2002). Que c'que ce l'auteur? Disponible en: http//www.fabula.org/compagnon /auteur.php. Recuperado el 12/02/2010.

Fernández, M. (2010). No toda es vigilia la de los ojos abiertos. Disponible en: http//www.seribd/ doc/122811182/No-toda-es-vigilia-La-de-los-ojos-abiertos-Macedonio-Fernandez. Recuperado el: 13/03/2010.

Lamborghini, O. (1966). El fiord. Disponible en: http//www.catedras.fsoc.uba.ar/rubinich/biblio teca/web/alambor.html. Recuperado el 23/02/2010.

Summary: In the new horizon of work production, the figure of the author appears as an amalgam of images that have been deposited through a labyrinth of manifestos, policies and activities that become the history of art and design, mainly in the last 100 years. Far from being clarified, the scenario of the last two decades has been blurred with the development of the new technological media. The author never has been an easy character to carry on; from his appearance in the dawn of modernity and within the geographic, cultural and philosophical European territory. In peripheral territories like ours, the problematic get rich with the polarization of the concepts of identity and strangeness.

Key words: anonymus - author - intertextuality - objectivity - realism - simulation - subjective.

Resumo: No novo horizonte de produção de obra, a figura do autor aparece como uma mistura de imagens que se foram depositando através de um laberinto de manifestos, políticas e actuações devenido história da arte e o design, sobre tudo nos últimos 100 anos. Longe de aclararse o panorama das últimas duas décadas se tem enturbiado com o desenvolvimento e a adoção dos novos meios tecnológicos, que problematizam ainda mais um panorama já complicado. O autor nunca foi uma figura fácil de levar com um, desde sua aparição nos albores da história da modernidade e dentro do território geográfico, cultural e filosófico europeu. Em territórios periféricos como os nossos, a problemática se enriquece com a polarização entre dois conceitos agonísticos: identidade e ajenidade, que jamais dormiram pacificamente num mesmo leito.

Palavras chave: anonimia - autor - intertextualidade - objetividade - parodia - realismo - subjetivização. 